\title{
DÍVIDA DOS ESTADOS - UNIÃO FEDERAL - RETENÇÃO DE RECURSOS
}

- Denegação de medida liminar suspensiva da execução de contrato entre a União e Estado-membro no tocante à retenção da transferência de recursos.

\section{SUPREMO TRIBUNAL FEDERAL}

Petição n⿳⺈ 1.665-3 (medida liminar)

Requerente: Estado de Minas Gerais

Requerida: União Federal

Relator: Sr. Ministro Moreira Alves

\section{Despacho do Relator}

DESPACHO: 1. O Estado de minas Gerais ajuizou perante esta Corte contra a União Federal, com pedido de concessão de liminar, medida cautelar inominada em procedimento preparatório da propositura de ação principal que terá como objeto a declaração de nulidade, bem como de revisão, de cláusulas do contrato $n^{2}$ 004/98/STN/COAFI que, em seu entender, violam frontalmente dispositivos constitucionais, notadamente aqueles ineren- 
tes ao pacto federativo e à autonomia dos Estados-membros.

Notícia o requerente quer, em virtude de "protocolo de Acordo" firmado com a União Federal em 26 de setembro de 1996, no qual se fixaram as diretrizes para a renegociação das dívidas dele, e de um segundo instrumento relativo à reestruturação do sistema financeiro estadual e à sua subseqüente privatização, ambos celebraram "contrato de confissão, promessa de assunção, consolidação e refinanciamento de dívidas" (contrato $\mathrm{n}^{\mathbf{2}}$ 004/98/STN/COAFI) nos moldes do previsto pela Lei $9.496 / 97$ e pela Resolução $99 / 96$ do Senado Federal, bem como o "contrato de abertura de crédito e de compra e venda de ações sob condição", para ser financiado o saneamento e a privatizaçāo do sistema financeiro estadual.

Alega o Estado de Minas Gerais que esses contratos, por estabelecerem garantias de auto-execução, violaram os princípios constitucionais norteadores do pacto federativo, impondo condiçōes draconianas e de impossível cumprimento a ponto de inviabilizar o cumprimento de obrigaçōes típicas do Poder Público, como as previstas no artigo 23 da Carta Magna, e de quebrar a harmonia entre as entidades federativas. E, com base na cláusula décima-oitava do contrato $\mathrm{n}^{2}$ 004/98/STN/ COAFI, a União vem retendo os recursos previstos nos artigos 157 e 159. I, "a" e II, da Constituição Federal, por causa da total incapacidade do requerente de cumprir, nos prazos e nas condições previstos no refinanciamento, as obrigações contratuais, retenção essa que traz irreparáveis danos à sua economia, inclusive para a continuidade dos serviços públicos essenciais e obrigatórios.

Em seguida, e tendo em vista que " $a$ pretensão do requerente é, na presente medida preparatória, lograr a imediata suspensão, através da obtenção de medida liminar, de cláusulas do citado ajuste", faz consideraçōes sobre sua precária e insustentável situação financeira, que alega ser decorrente, em larga medida, do próprio contrato questionado. Para isso, expõe, primeiramente, os antecedentes das negociaçōes que precederam à assinatura dos contratos com a União, procu- rando demonstrar que tinha esta, de longa data, conhecimento da deterioração das contas públicos de Minas Gerais, tanto que as metas e compromissos constantes do programa de reestruturação e de ajuste fiscal foram descumpridos pelo Estado com o conhecimento e o beneplácito da Uniāo, a traduzir o reconhecimento desta de que ele estava impossibilitado de adimplir suas obrigações, o que significa que, desde o início, as partes sabiam que as condições contratuais não poderiam ser honradas pelo requerente. Ademais, o Estado pôde arar com os compromissos financeiros nos nove primeiros meses do contrato, só deixando de podê-lo em janeiro deste ano porque, pelo contrato, as prestações mensais nesses nove meses equivaliam a $1 / 12$ de $6,79 \%$ da receita líquida real estadual, o que, nos demais meses de 1998, aumentou para $1 / 12$ de $12 \%$, e durante o exercício de 1999 passará para $1 / 12$ de $12,5 \%$. Aliás, quando o patamar se tornou $12 \%$, o que ocorreu em novembro de 1998, a Medida Provisória 1.702 prorrogou para 30 de novembro de 1999 o vencimento daquela parcela. Descreve, então, o requerente sua situação financeira, com base em relatórios da Administração Estadual submetidos à auditoria do Tribunal de Contas do Estado, para demonstrar que sua situação é de inequívoca insolvência, sendo que o impacto do contrato de renegociaçāo é devastador, até porque "tendo parcelas substantiva da divida mobiliária sido transformada em divida contratual com a União, insuscetivel de rolagem, terá o Estado que efetuar desembolso líqüido de recurso do Tesouro superior a 90 milhōes por mês ou mais de l, l bilhão por ano", o que o onerará por prazo mínimo de 30 anos, com a possibilidade de resíduo e isso por ter sido estabelecido teto de $13 \%$ de comprometimento da receita líquida com o pagamento da dívida - a ser pago nos 10 anos subsequientes. Sustenta, então, o requerente a responsabilidade da União por seus problemas financeiros, em face da política de juros acachapantes, da impossibilidade de poder o Estado fazer a rolagem de sua dívida mobiliária por causa do contrato de renegociação, da falta de êxito do programa de alienação de ativos e privatizações em massa, da 
inexistência de lei de fixação de plano econômico por meio de normas gerais, por nāo terem sido alcançadas as reformas administrativa, fiscal e tributária, do retraimento da arrecadação pelo quadro econômico recessivo decorrente da política da Uniāo.

Justifica o requerente a propositura da presente medida cautelar inominada perante esta Corte por se tratar de lide entre Estado-membro e União Federal.

No mérito, principia o Estado de Minas Gerais a sustentar que, em razão das peculiaridades do Estado Federal e do Estado democrático de direito, o princípio " pacta sunt servanda" se altera. Invoca o modelo do federalismo cooperativo que pressupōe lealdade recíproca e solidariedade entre os entes federativos, para salientar que nos contratos entre eles não se aplica, na sua totalidade, o referido princípio, nem a justiça comutativa, mas, sim, a justiça distributiva. Acentua que, mesmo se se tratasse de contrato de direito privado, observar-se-iam os princípios da equivalência entre as prestações e a comulatividade, bem como os institutos da excessiva onerosidade e da lesão. Além disso, na responsabilidade civil, o estado de necessidade afasta a ilicitude do ato, e há autores que admitem a indenização por arbitramento do juiz "ex bono et aequo" e não a ampla e comum. De outra parte, os contratos firmados entre os Estados-membros e a União não configuram contrato administrativo que admite cláusulas exorbitantes, pois nele não há relação de subordinação entre os contratantes, mas relação de coordenação, motivo por que esses contratos se aproximam dos acordos firmados entre países soberanos, onde não se admite a cobrança coercitiva de débitos.

A seguir, sustenta o requerente a inconstitucionalidade das cláusulas que acarretam para o Estado gravíssimas consequiências no caso de descumprimento por parte dele de quaisquer obrigaçōes assumida no contrato. Essas sançōes financeiras cassam a autonomia financeira do Estado e comprometem a normalidade da administração estadual e o funcionamento harmônico entre os Poderes estaduais, com expropriação de receitas próprias do Estado e retençōes de parcelas devidas a ele.
Impugna, então, as cláusulas décima-sétima e décima-oitava do contrato 004/98/STN/ COAFI, das quais o teor é este:

"CLÁUSULA DÉCIMA-SÉTIMA - O ESTADO se obriga, durante toda a vigência deste Contrato, a manter conta de depósitos no AGENTE, suprindo-a com recursos suficientes à cobertura dos compromissos decorrentes deste Contrato em seus vencimentos, $e$ autoriza o AGENTE, em caráter irrevogável e irretratável, independentemente de qualquer aviso ou notificação, a efetuar débitos

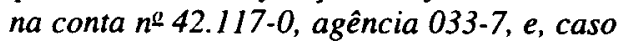
esses recursos não satisfaçam a totalidade do débito, o ESTADO autoriza o DEPOSITÁ$R I O$, em caráter irrevogável e irretratável, a transferir ao AGENTE, mediante débito à conta de centralização de receitas próprias do ESTADO, Agência 002-6, Cidade de Belo Horizonte, conta corrente $n^{0} 127.000-8$, quantias suficientes à liquidação das obrigacões financeiras ora pactuadas.

PARÁGRAFO ÚNICO - O ESTADO se compromete a manter a conta de centralização de receitas referidas no "caput" e a somente substituir a instituição depositária após comunicação à UNIÃO, por intermédio da Secretaria do Tesouro Nacional e ciência do AGENTE, e desde que a nova instituiçāo depositária se manifeste formalmente de acordo com os termos deste Contrato, no que se refere às obrigações do DEPOSITÁRIO.

CLÁUSULA DÉCIMA-OITAVA - O ES$T A D O$, devidamente autorizado pelas Leis Estaduais $n^{2} s$ 12.422, de 27.12.96, 12.731, de 30.12.97, e 12.746, de 8.1.98, transfere à UNIÃO, mediante cessão, condicionada à ocorrência de inadimplemento das obrigações ora pactuadas, a título "pro solvendo", os recursos provenientes das receitas de que tratam os artigos 155, 157 e 159, incisos 1 , alínea " $a$ ", e II, da Constituição, até os montantes devidos e nāo pagos, inclusive encargos, e, neste ano, confere poderes, em caráter irrevogável e irretratável, à UNIÃO, por si ou por intermédio do AGENTE, para:

$I$ - transferir as cotas das receitas tributárias a que se refere o artigo 159 da Constituiçāo, creditadas no Banco do Brasil S/A, Agência 033-7, Cidade de Belo Horizonte, Conta Corrente n 42.117-0; $e$ 
II - requerer a transferência de recursos, até o limite do saldo existente, da conta de centralização de receitas próprias do ESTADO no DEPOSITÁRIO, Agência 002-6, Cidade de Belo Horizonte, conta corrente $n^{\varrho}$ 127.000-8.

III - transferir as cotas das receitas tributárias a que se refere o item I do anexo à Lei Complementar $n^{0} 87$, de 13 de setembro de 1996, creditadas no Banco do Brasil S/A, Agência ñ 033-7, Cidade de Belo Horizonte. $M G$, Conta-Corrente no 42.117-0.

PARÁGRAFO PRIMEIRO - Para efetivação da cessão e transferência a que se refere esta Cláusula, a UNIĀO, por si ou por intermédio do AGENTE, informará ao DEPOSITÁRIO, o valor da importância a the ser transferida.

PARÁGRAFO SEGUNDO - O ESTADO se obriga a adotar, no âmbito de sua competência, as medidas necessárias para complementar as garantias ora ajustadas, mediante solicitaçāo justificada da UNIÃO.

PARÁGRAFO TERCEIRO - O DEPOSITÁRIO se obriga, neste ato, em caráter irrevogável e irretratável, a transferir, no prazo máximo de I (um) dia útil, até o limite dos saldos existentes, mediante requisição da UNIÃO ou do AGENTE, os valores necessários ao pagamento das obrigações decorrentes deste Contrato, sob pena de multa diária de $1 \%$ (um por cento) do valor requisitado".

Alega que essa retençāo incondicional e absoluta viola o "caput" do artigo 160 , o artigo 167, IV, e $\$ 4^{2}$, todos da Constituição Federal, bem como o princípio federativo.

Entende o estado de Minas Gerais que a vedação contida no "caput" do artigo 160 da Carta Magna não pode estar afastada pela ressalva de seu parágrafo único que, assim, permitiria à União condicionar a entrada dos recursos próprios do Estado ao prévio pagamento dos créditos dela, porque então esse parágrafo anularia o princípio do "caput". A interpretação teleológica impõe que, havendo dois tipos de transferência federal para os outros entes políticos da federação - as transferências obrigatórias (do que originariamente pertence a esses entes, sendo apenas arrecadado pela União) e as transferências volun- tárias (do que decorre de convênio ou pacto específico que visa a suplementar recursos para determinado programa, havendo, pois, transferência voluntária desses recursos) o parágrafo único desse artigo 160 (que não repete a expressão "recursos atribuídos nesta Seção", mas alude apenas a "recursos") só se aplica a essas transferências voluntárias. Ademais, no direito obrigacional, retenção não se confunde com compensação, sendo que, pela conceituação civil dessas duas figuras, nenhuma delas se aplica ao caso, pois nele não estāo presentes os requisitos de uma ou de outra. Acresce notar que, ainda quando assim nāo fosse, esse parágrafo único pressuporia o inadimplemento puro, simples e injustificado, e não aqueles que "encontram abrigo quer na força maior, quer na imprevisão ou onerosidade excessiva, quer no estado de necessidade".

De outra parte, em virtude do disposto em seu artigos 100 e 167 , IV, e $\$ 4$, a Carta Magna Federal, no entender do requerente proíbe a garantia real e a cessão ou alienação das rendas públicas, especialmente a execução extrajudicial destas. Do exame do artigo 167 , IV, e $\$ 4^{\circ}$, resulta que, sendo necessário distinguir vinculação, garantia, contragarantia e atos de execução material extrajudicial), a permissão do referido $\S 4^{\circ}$ se restringe à vinculação da receita de impostos para a prestação de garantia e contragarantia à Uniāo e não lhe dá poder de execução extrajudicial dessas garantias, até por serem a receita e a renda pública absolutamente inalienáveis $e$ impenhoráveis, o que não pode ser afastado por lei estadual. A receita pode ser dada em garantia ou em contragarantia de pagamento, mas em face de sua impenhorabilidade, não pode ser oferecida como garantia real, "porque, se o for, a pretendida garantia estará despida de toda execução direta sobre a coisa onerada", e isso com base no artigo $100 \mathrm{da}$ Constituição Federal que "nāo abre exceções à penhorabilidade, que se estende a qualquer garantia real".

Salienta o requerente que, apesar da aparente licença da Constituição para a retenção dos fundos federais dos Estados, ainda que ele tenha outras fontes de receita, a ação da União 
só se legitima se houver descumprimento injustificado do pagamento. A autorização do Estado de Minas para a expropriação de sua receita própria afronta a Constituição, o mesmo ocorrendo com a expropriação exercida pela União. Tudo isso fere a autonomia do Estado-membro no concerto federativo.

Mas - prossegue o requerente - quando não fossem inconstitucionais as sanções pactuadas que levam à execução extrajudicial, nāo deveriam elas ser aplicadas "quer em decorrência de força maior, que em decorrência de onerosidade excessiva ou de estado de necessidade administrativa". No campo do direito privado, a particular pode invocar a força maior para afastar as consequiências do não cumprimento do contrato, o mesmo devendo ocorrer no caso "sub judice", pois a redução de receita de Minas Gerais resultou de fatos que não lhe são imputáveis, e, se eles foram vencidos por outros Estados com dívida mais reduzida, ainda assim devem isentar o requerente de responsabilidade, pois esses fatos foram provocados pela própria União. Por outro lado, também no direito privado se aplica a teoria da imprevisão que, segundo a doutrina e a jurisprudência, autoriza a revisão de cláusulas contratuais consideradas desproporcionais em razão de fatos supervenientes que as tornem excessivamente onerosas, sendo que o Código do Consumidor não exige sequer os fatos supervenientes sejam extraordinários ou imprevisíveis para que seja possível essa revisāo, devendo o Estado-membro ter também essa proteção dada ao cidadão comum consumidor. Há ainda que se levar em consideração que, no caso, há, em favor do requerente, estado de necessidade administrativo excludente da responsaiblidade dele. No primeiro trimestre de 1999 , estará ele colocado diante de alternativas dramáticas, como honrar a dívida ou pagar o $13^{\circ}$ salário não pago e até a folha normal de salários, sendo que também está obrigado a garantir o livre exercício dos Poderes, aplicar o mínimo de receita no ensino e pagar sua dívida fundada para que no futuro não dê causa a intervenção federal. Embora a Constituição federal não o diga, nem a estadual, há prioridade no pagamento das obrigaçōes estaduais com o salário do pessoal além dos pagamentos cuja falta pode dar margem a intervenção por parte da União, que, assim, não pode obstar esses pagamentos com a retenção dos fundos ou a expropriaçāo das receitas do Estado. Esse estado de necessidade administrativo é excludente da ilicitude, nem sempre ensejando indenizaçāo, como, entre outras hipóteses, quando as partes contratantes sejam igualmente obrigadas a cumprir a Constituição e as leis, ou quando elas tenham reciprocamente deveres de legalidade e de solidariedade, ou quando soluçāo diversas atenderia a um interesse da Uniāo, interesse inferior ao cumprimento de um dever constitucional.

Acentua, também, o requerente que o pagamento automático da dívida com a Uniāo traz graves e irreparáveis lesões à economia pública estadual, comprometendo o funcionamento regular dos três Poderes (inclusive a transferência de duodécimos), o ensino, a segurança, a saúde, o pagamento de pretórios, os meios de sobrevivência do funcionalismo, no passo que a União não sofrerá danos, pois "além de dispor de meios para suprir a ausência de recursos como política monetária $e$ de juros, aumento de impostos ou criação de novos, ela poderá rolar a dívida ou captar recursos no mercado".

Esclarece o Estado de Minas que, atendendo ao artigo 801, III, do C.P.C., a ação principal a ser proposta no prazo estipulado no art. 806 do mesmo Código, terá como objeto a declaração de nulidade, bem como de revisão, de cláusulas do contrato ne 004/98/STN/ COAFI por violação a princípios constitucionais, especialmente os inerentes ao pacto federativo e à autonomia dos Estados-membros.

Quanto à concessāo da medida liminar, diz o requerente que a plausibilidade do pedido ficou amplamente demonstrada, seja "pela inequivoca violação dos princípios norteadores do pacto federativo, seja pelo malferimento dos artigos $I^{2}, 2^{\circ}, 24, \S 4^{\circ}, 23,25,34,60$, $\S 40,100,160$, "caput", 166, §3, II, 167, III e IV e § 4, da Constituição Federal”. Além disso, suficientemente provado está também o "periculum in mora" pela impossibilidade de o Estado utilizar a totalidade de seus recursos em razāo da ação da União Federal. 
E, no capítulo referente ao pedido, requer se suspenda "inaudita altera parte" a eficácia das cláusulas $17 \mathrm{a}, 18^{\mathrm{a}}, 20^{\mathrm{a}}, 21^{\mathrm{a}}$ e $22^{\mathrm{a}}$ do contrato 004/98/STN/COAFI, determinando-se, em consequiência, à União que até a decisāo final na açāo principal:

“a) - suspenda o bloqueio de recursos provenientes das receitas previstas nos arts. 155, 157 e 159, I, "a”, e II, da Constituição Federal e das cotas de compensação previstas na Lei Complementar $n^{0}$ 87, de 13 de setembro de 1996;

b) - que restitua ao Estado de Minas Gerais, de imediato, as parcelas já indevidamente bloqueadas;

c) - que se abstenha de apropriar de qualquer parcela de recursos, provenientes da arrecadação própria do Estado e de praticar qualquer outro ato previsto no contrato, como decorrência da impossibilidade financeira do Estado de Minas Gerais de adimplir as par. celas como pactuado, até o julgamento final da ação principal;

d) - que assegure o fiel cumprimento das normas constitucionais invocadas, especialmente o art. 168 da Constituição Federal, que impõe a entrega dos créditos do Poder Judiciário, do Poder Legislativo e do Ministério Público;

e) - que seja determinado ao Banco do Brasil S/A e ao Banco do Estado de Minas Gerais S/A - BEMGE, na qualidade de, respectivamente, agente e depositário que se abstenham da prática de qualquer dos atos previstos nas cláusulas décima-sétima (17a) $e$ décima-oitava (18a) do referido contrato, inclusive para assegurar a integridade dos repasses dos duodécimos aos Poderes Legislativo e Judiciário, bem como ao Ministério Público".

Por fim, faz o requerente pedido alternativo, para o caso de se considerar provada a sua insolvência e a obrigatoriedade imposta pela Constituição de ele custear as despesas prioritárias, no sentido de que se conceda a medida liminar como requerida anteriormente,

“a) - mediante a comprovação mensal pelo requerente, devidamente atestado pelo Tribunal de Contas do Estado de Minas Gerais, da inequívoca impossibilidade econômi- co-financeira do Estado, sendo certo que a comprovação deverá ser feita até o dia 28 do mês seguinte;

b) - prestação de caução mensal, cujo valor será a diferença entre a arrecadação estadual, incluindo as transferências dos recursos previstos nos artigos 155, 157, 159, I, “ $a$ ", e II, da Constituição Federal, e o custeio das despesas prioritárias e obrigatórias estabelecidas pela Carta Magna, devendo a caução ser feita mediante depósito à disposição do Supremo Tribunal Federal, a partir do mês em que as finanças do Estado permitirem o pagamento à Uniäo".

2. Para se examinarem os dois requisitos para a concessão da liminar requerida -0 "fumus boni iuris" e o "periculum in mora" —, é necessário, preliminarmente, que se determine a natureza jurídica do contrato de confissão, promessa de assunção, consolidação e refinanciamento de dívidas (contrato $\mathrm{n}^{\mathbf{2}}$ 004/98/STN/COAFI) firmado entre a União Federal e o Estado de Minas Gerais, do qual cinco cláusulas deverão ser objeto da ação principal que visará à declaração de sua nulidade ou de sua revisão.

Tendo em vista que se trata de contrato entre duas pessoas jurídicas de direito público interno - a União Federal e o Estado-membro de Minas Gerais - que estão em relação de coordenação e não de subordinação de um em face do outro, e contrato a que, por seu objeto, não se aplicam os princípios e as regras do direito administrativo, enquadra-se ele no que alguns autores (assim, CRETELA JÚNIOR, “Tratado de Direito Administrativo", vol. III, p. 16, Forense, Rio-São Paulo, 1967) denominam "contratos privados da administraçào" e outros (assim, LÚCIA VALLE FIGUEIREDO, "Curso de Direito Administrativo", $2^{2}$ ed., p. 329, Malheiros Editores, São Paulo, 1995), a meu ver com maior razão, designam, em contraposição aos "contratos administrativos", como "contratos da Administração Pública”, por terem de observar sob muitos aspectos o regime contratual do direito público, embora se submetam basicamente às normas contratuais do direito privado.

3. Determinada a natureza jurídica do contrato em causa, passo a examinar a ocorrência, 
ou não, do "fumus boni iuris" relativo à liminar requerida na presente medida cautelar inominada, e que diz respeito, como, a meu ver corretamente, acentua CALMON DE PASSOS ("Comentários ao Código de Processo Civil", vol. X, Tomo I, n' 54 e 111-3, p. 54 e 134/135, Editora Revista dos Tribunais, São Paulo, 1984), à plausibilidade do direito que se pretende tutelar com a ação principal.

Tendo em vista o pedido alternativo que, segundo a inicial desta media cautelar inominada, se fará na ação principal a ser proposta - o da nulidade das cláusulas $17^{\mathrm{a}}, 18^{\mathrm{a}}, 20^{\mathrm{a}}$, $21^{\mathbf{a}}$ e $22^{\mathbf{a}}$ do contrato em causa por ofensa a normas constitucionais e o da revisão delas em decorrência da insolvência do Estado de Minas Gerais por culpa da Uniāo Federal examinarei esse requisito primeiramente em face das alegaçōes de nulidades dessas cláusulas e, depois, diante da pretendida revisão delas.

4. No tocante à nulidade dessas cláusulas por ofensa a normas constitucionais, observo, de início, que a sustentação dessa violação só se faz com referência às cláusulas $17^{\mathrm{a}} \mathrm{e} 18^{\mathrm{a}}$, nenhuma fundamentação existindo a esse respeito quanto às cláusulas $20^{\mathrm{a}} ; 21^{\mathrm{a}}$ e $22^{2}$, que rezam, respectivamente:

“ CLÁUSULA VIGÉSIMA - Enquanto a divida financeira do ESTADO for superior a sua RLR anual, o ESTADO:

$I$ - não poderá emitir novos títulos públicos no mercado interno, exceto nos casos previstos no art. 33 do Ato das Disposições Constitucionais Transitórias;

$I I$ - somente poderá contrair novas dívidas, inclusive empréstimos externos junto a organismos financeiros internacionais, se cumprir as metas relativas à dívidas financeira na trajetória estabelecida no Programa de Reestruturação e de Ajuste Fiscal com exceção das seguintes operações relativas a projetos de interesse do ESTADO já aprovados pelo Governo Federal: BNB/PRODETUR, BNDES/CVRD, BIRD/REFORMA DO ESTADO e BIRD/ESTRADAS;

III - não poderá atribuir a suas instituiçōes financeiras a administração de títulos estaduais e municipais junto a centrais de custódia de títulos e valores mobiliários, ex- ceto aqueles que. emitidos com base no art. 33 do Ato das Disposições Constitucionais Transitórias, não foram objeto do refinanciamento de que trata este Contrato;

CLÁUSULA VIGÉSIMA PRIMEIRA - O descumprimento pelo ESTADO de qualquer das obrigações assumidas neste Contrato, ou nos contratos dele integrantes, incluindo atraso de pagamento e nāo observância das metas e compromissos constantes do Programa de reestruturação e de Ajuste Fiscal, a que se refere a Cláusula Décima Nona, implicará, durante todo o período em que persistir o descumprimento, (1) a substituição dos encargos financeiros mencionados na Cláusula Décima por encargos equivalentes ao custo médio de captação da dívida mobiliária interna do Governo Federal, acrescido de juros moratórios de $1 \%$ a.a. (um por cento ao ano), e (II) a elevação, em quatro pontos percentuais, do percentual da RLR tomado como base para a apuração do limite de dispêndio mensal previsto nas Cláusulas Quinta a Nona; e

CLÁUSULA VIGÉSIMA SEGUNDA - Na falta de cumprimento de qualquer das obrigações do ESTADO assumidas neste Contrato, ou pela ocorrência de qualquer dos casos de antecipação legal de vencimento, poderá a UNIÄO considerar vencido este Contrato e exigir o total da dívida dele resultante, independentemente de aviso extrajudicial ou interpelação judicial".

Ora, é dever processual do requerente de liminar fundamentar especificamente a ocorrência, no seu entender, dos requisitos para a concessão dela, máxime quando se alega genericamente ofensa a diversos dispositivos constitucionais e as cláusulas tidas como atentatórias a princípios norteadores do pacto federativo, ou são reprodução de dispositivos, que gozam da presunção de constitucionalidade, da Lei — a de $\mathrm{n}^{2}$ 9.496, de 11 de setembro de 1997 - que estabeleceu "os critérios para a consolidação, a assunção $e o$ refinanciamento, pela União, da dívida pública mobiliária e outras que especifica, de responsabilidade dos Estados e do Distrito Federal" e da Resoluçāo n 44/98 do Senado Federal que autorizou o Estado de Minas Ge- 
rais a celebrar o contrato em causa, ou são cláusulas normais de consequiência de inadimplemento contratual. Com efeito, a cláusula $20^{3}$ foi aposta ao contrato em estrita obediência ao critério (que produz quase literalmente) estabelecido no artigo $3^{\circ}, \S 5^{\circ}$, da Lei $n^{2}$ $9.496 / 97$; a cláusula $21^{\mathrm{a}}$ obedece rigorosamente ao critério fixado no artigo $3^{\circ}, \S 6^{\circ}$, da Lei $\mathrm{n}^{2}$ 9.496/97 e está em conformidade com o disposto no artigo $2^{2}, \S 2^{2}$, da Resolução $n^{2}$ $44 / 98$ do Senado Federal; e a cláusula $22^{\mathrm{a}}$ é cláusula normal de vencimento antecipado de contrato com o objeto deste, seja por inadimplemento, seja por ocorrência de caso de antecipação legal.

Não havendo qualquer demonstraçāo das razōes constitucionais por que o requerente não poderia ter celebrado o contrato com essas três claúsulas, não há como se considerar a plausibilidade do direito alegado por ele para o efeito de concessão de liminar com relação a elas.

Já com referência às alegadas ofensas à Constituição no tocante às cláusulas $17^{\mathrm{a}} \mathrm{e} 18^{\mathrm{a}}$ do contrato, o requerente longamente procurou demonstrar o "fumus bani iuris" dessa alegação para o efeito de nulidade de tais cláusulas.

Não me parece, porém, que o Estado de Minas Gerais tenha demonstrado, ao menos nesse exame mais sumário para a concessão de liminar, esse "fumus obni iuris".

As cláusulas $17^{\mathrm{a}}$ e $18^{\mathrm{a}}$ decorreram do critério estabelecido no artigo $4^{0} \mathrm{da}$ Lei $\mathrm{n}^{2}$ 9.496/97 ("Os contratos de refinanciamento deverāo contar com adequadas garantias que incluirão, obrigatoriamente, a vinculação de receitas próprias e dos recursos de que tratam os artigos 155, 157 e 159, incisos I, “a”, e II, da Constituição Federal, de 5 de outubro de 1988") e do previsto no inciso IV do artigo $2^{2}$ da Resolução n $44 / 98$ do Senado Federal ("IV: garantias; receitas próprias do Estado, as transferências constitucionais e os créditos de que trata a Lei Complementar $n^{2} 87$, de 13 de setembro de 1996").

A vedação do "caput" do artigo 160 da Constituição, que diz respeito aos recursos atribuídos aos Estados na Seção "Da repartição das receitas tributárias”, é excepcionada pelo seu parágrafo único que dispõe que " $a$ vedação prevista neste artigo não impede a União e os Estados de condicionarem a entrega de recursos ao pagamento de seus créditos, inclusive de suas autarquias". A interpretação do requerente no sentido de que os recursos a que alude esse parágrafo único não seriam os referidos no "caput", mas somente os resultantes das transferências voluntárias feitas pela União em virtude de convênio ou pacto para a suplementação de recursos para determinado programa, não se compadece com a circunstância de que, numa seção que disciplina as transferências obrigatórias a ser feitas pela Uniāo, e em que, a respeito delas, há a vedaçāo de retenção prevista no "caput" desse artigo 160 , a exclusão de vedação de retenção contida no parágrafo único somente pode referir-se a essas transferências, e não a outras que, além de não estarem expressamente mencionadas, têm natureza complemente estranha a al seção e ao "caput" do artigo a que logicamente se prende o parágrafo único, e transferências que, por serem voluntárias, não estão sujeitas a nenhuma vedação constitucional que necessite de ser afastada por exceçāo contida em dispositivo dessa mesma Constituiçāo. Ademais, a exceção do parágrafo único não anula o princípio do "caput", pois ela se aplica, no tocante à Uniāo, somente quando há créditos desta e de suas autarquias em face do Estado, e nāo em outras hipóteses. É de notar-se, ainda, que, como acentua MANOEL GONÇALVES FERREIRA FILHO ("Comentários à Constituição Brasileira de 1988”, vol. III, p. 133, Saraiva, São Paulo, 1994), essa retenção pode implicar constitucionalmente compensação: "Ressarcimento de crédito da União. Somente este condicionamento é admitido quanto à entrega de recursos pela União aos Estados, ao Distrito Federal e aos Municípios. Pode assim ocorrer a compensação entre os débitos para com a União e autarquias, e o crédito do ente federativo a transferência federais". No mesmo sentido, em face do texto originário do parágrafo único do artigo 160 que continha a mesma norma com referência à União Federal, PINTO FERREIRA ("Comentários à Constituiçāo Brasileira”, vol. V, p. 511, Sa- 
raiva, São Paulo, 1992) anotou: “A União está dotada de dois direitos; a) o direito de retenção, quando os seus créditos não forem pagos; b) o direito de compensaçāo, pagando somente às pessoas de direito público os créditos que devem receber, com os descontos de que devem". E, como se trata de retenção e de compensação que resultam da Constituição não estāo ambas sujeitas evidentemente aos requisitos que decorrem da conceituação civil desses dois institutos jurídicos.

Por outro lado, quanto à vedação de vinculação de receitas próprias do Estado-membro contida, com a redação advinda da Emenda n 3/93, no inciso IV do artigo 167 , é ela, na parte final desse mesmo dispositivo, ressalvada com referência ao disposto no $\$ 4^{\circ}$ dele, que reza: “É permitida a vinculafão de receitas próprias geradas pelos impostos a que se referem os arts. 155 e 156, e dos recursos de que tratam os arts. 157, 158 e 159, $I$, “ $a$ " e " $b$ ", e II, para a prestação de garantia ou contragarantia à União e para pagamento de débitos para com esta". Portanto, é a própria Constituição que permite a vinculação dessas receitas próprias e desses recursos nảo só para a prestação de garantia à União Federal, mas também para pagamento de débitos para com esta. Se essas garantias se destinam elas mesmas ao pagamento de débitos para com a União Federal, e, portanto, têm natureza dê garantia reais, nāo se me afigura, ao menos de planos, que a forma de execução extrajudicial prevista na cláusula $18^{\mathrm{a}}$ (transferência, devidamente autorizada pela legislaçāo estadual, à União, mediante cessāo, condicionada à ocorrência de inadimplemento das obrigações pactuadas, a título "por solvendo"), que possibilita a efetiva viabilização dessa garantia constitucional em que as receitas seu objeto continuam em poder do devedor, seja inconstitucional. E em se tratando de execução de garantia real admitida constitucionalmente, não há que se invocar ofensa ao artigo 100 da Carta Magna que se refere a pagamento, em virtude de sentença judicial, dos débitos da Fazenda Pública que correspondem aos créditos que não tenham garantia dessa natureza que é excepcionalmente permitida pela própria Constituição.
É, ainda, de observar-se que, se essas duas cláusulas se apoiam, como decorre desse exame sumário, em preceitos constitucionais específicos, nāo se pode sustentar que elas, que foram aceitas pelo Estado de Minas Gerais, inclusive com autorização legislativa específica, sejam inconciliáveis com a autonomia estadual e com o princípio federativo.

Por fim, a alegação de que essas cláusulas só poderiam aplicar-se se houvesse inadimplemento injustificado, o que, no caso, não ocorreria pela existência de força maior, diz respeito, não à inconstitucionalidade de tais cláusulas ou à revisāo delas, mas, sim, à sua incorreta aplicação (execução de garantia por falta de pagamento que não seria devido pela impossibilidade objetiva e absoluta de adimplemento de obrigação), o que não se enquadra nos limites da ação principal a ser proposta, os quais, segundo a inicial desta medida cautelar, se adstringirāo aos dois referidos aspectos. Tal alegação, pois, não é susceptível de apreciação neste exame da liminar requerida.

5. No concernente a que as cláusulas impugnadas, ainda que nāo fossem consideradas inconstitucionais, não poderiam ser utilizadas contra o requerente "em decorrência de onerosidade excessiva ou de estado de necessidade administrativo", essa pretensāo só se pode prender ao pedido alternativo que deverá fazer na ação principal e é o da revisão dessas cláusulas em decorrência da insolvência do Estado de Minas Gerais resultante da atuação da União no plano econômico.

Também a esse respeito, em exame compatível com pedido de liminar, não tenho por demonstrado o "fumus boni iuris".

Não há dúvida de que o princípio "pacta sunt servanda", quer no campo dos contratos privados, quer no terreno dos contratos públicos, inclusive administrativos, não tem caráter absoluto no direito moderno. No Brasil, doutrina e jurisprudência admitem, embora com cautela principalmente por parte desta, $o$ princípio que vem da antiga cláusula "rebus sic stantibus" e que modernamente se apresenta em modalidades como a da "teoria da imprevisão" ou a da "onerosidade excessiva", afastando-se, quando ocorrem seus re- 
quisitos, a imutabilidade do pactuado nos contratos comutativos de trato sucessivo, para admitir sua resolução ou, às vezes, sua revisão. Civilistas e publicistas salientam que essas teorias só se aplicam a tais contratos quando se verificarem os requisitos assim arrolados por CAIO MÁRIO DA SILVA PEREIRA ("Instituição de Direito Civil", vol. III, 5a ed., $\mathrm{n}^{\mathrm{Q}} 216$, p. 141, Forense, Rio de Janeiro, 1981): "Para que se possa, sob fundamento na teoria da imprevisão, atingir o contrato, é necessário concorram requisitos de apuração certa: a) vigência de um contrato de execução diferida ou sucessiva; b) alteração radical das condições econômicas objetivas no momento da execução, em confronto com o ambiente objetivo da celebração; c) onerosidade exces. siva para um dos contratantes e beneficio exagerado para o outro; d) imprevisibilidade daquela modificação". E HELY LOPES MEIRELLES ("Direito Administrativo Brasileiro, 23 $\mathrm{ed}$., p. 212, Malheiros Editores, Sāo Paulo, 1998) acentua que a teoria da imprevisão "é a aplicação da velha cláusula "rebus sic stantibus" aos contratos administrativos, a exemplo do que ocorre no ajustes privados, a fim de que sua execução se realize com a ruína do contratado, na superveniência de fatos não cogitados pelas partes, criando ônus excessivo para uma delas, com vantagem desmedida para a outra".

Ora, no caso, não se apresentam, de plano, esses requisitos. Com efeito, trata-se de um contrato de confissão, promessa de assunção e refinanciamento de dívidas, pelo qual a União Federal assumiu a dívida mobiliária do Estado em face dos credores privados deste a custos de mercado, enquanto o Estado de Minas Gerais passou a dever à União com o benefício de taxa fixa de juros, muito inferior à de mercado, e com o comprometimento de sua receita líquida, no ano de 1999 limitado a $12 \%$ e a $13 \%$ a partir do ano 2000 . Só por isso se vê que é difícil de sustentar que, em decorrência das condições econômicas objetivas no momento da execução em confronto com o ambiente objetivo no da celebraçāo (ocorrida em fevereiro de 1998), está havendo, no cumprimento desse contrato, onerosidade excessiva para o requerente e benefício exagerado para a Uniāo Federal. Aliás, o próprio requerente. a fls. 35 . no item 155 , em face da assunção de sua dívida pela União, diz que esta, sem a execução de suas garantias, não sofrerá danos, porque "além de dispor de meios para suprir a ausência de recursos como política monetária e de juros, aumento de impostos ou criação de novos, ela poderá rolar a divida ou captar recursos no mercado", o que, ao contrário, evidencia que ela sofrerá danos, com o aumento da dívida pública interna em virtude da rodagem dos débitos decorrentes dessa assunção de dívida mobiliária ou com a necessidade de captaçāo de recursos no mercado aos custos deste, e, para fazer face a eles, terá de repassá-los aos contribuintes, inclusive do Estado de Minas, com o aumento de impostos ou com a criação de novos. Ademais, não só não houve radial alteraçāo nas condições econômicas existentes quando da celebração do contrato, porque já então havia graves problemas com o plano de que resultara a instituição do real, como o do desemprego, o da recessão econômica, o das evidentes dificuldades da aprovação e da implantação das reformas constitucionais pretendidas e o dos efeitos da vigência da Lei complementar $n^{9} 87 / 96$, mas também era perfeitamente previsível o agravamento dessas dificuldades à medida em que o tempo passasse. E, note-se, por fim, que, ainda quando se entenda que o denominado Código do Consumidor, na parte final do inciso $\mathrm{V}$ do artigo $6^{2}$, tenha adotado o princípio da excessiva onerosidade sem o requisito da imprevisibilidade para permitir a revisāo do contrato, essa norma se destina, nas relaçōes de consumo, à defesa da parte tida como mais fraca, que é o consumidor, o que não ocorre, evidentemente — daí não ser possível aplicar-se por analogia esse princípio especial - , quando se trata de contrato firmado entre a União e Estadosmembros, ambos devidamente autorizados por lei. Além disso, é preciso, mesmo em se tratando de consumidor, que haja grave desequilíbrio entre prestação e contraprestação, tornando-se esta excessivamente onerosa para o consumidor e, portanto, excessivamente vantajosa para a outra parte contratante, o que, no caso, não se dá. 
Por outro lado, o estado de necessidade, quer no 'direito público, quer no direito privado, não dá margem à resolução de contrato ou à revisão de cláusulas contratuais. É ele circunstância excludente de ilícito absoluto e, consequientemente, de responsabilidade civil extra-contratual, e não de ilícito relativo como o é o inadimplemento contratual. BIELSA ("Derecho Administrativo", tomo I, 6a, ed., n²3, II, p. 114, La Ley, Buenos Aires, 1964), tratando do estado de necessidade do direito administrativo, salienta: "No direito administrativo o estado de necessidade, como justifi. cativa do dano causado pelo poder público, determina a isençāo de responsabilidade do Estado ou de seus agentes"("En el derecho administrativo el estado de necessidad, como justitificativo del daño causado por el poder público, determina la exención de responsabilidad del Estado o de sus agentes"). No mesmo sentido, CRETELLA JÚNIOR (Ob. Cit., vol. VIII, $\mathrm{n}^{\mathrm{2}} 71$, p. 103, Forense, Rio-São Paulo, 1970), examinando a responsabilidade extra-contratual do Estado, observa que " $o$ estado de necessidade é também exclusivo da obrigação de indenizar e, portanto, da responsabilidade, afigurando-se como situação em que predomina $o$ interesse geral sobe $o$ interesse pessoal, conveniência e mesmo direitos individuais". E no Código Civil brasileiro o estado de necessidade está previsto no inciso II e no parágrafo único do artigo 160 como circunstância excludente do ato ilícito absoluto que é definido no artigo 159.

6. Se não se reconhece, de plano, o "fumus boni iuris", e, portanto a plausibilidade do direito que se quer tutelar, não há que se pretender ocorra o "periculum in mora", que, em se tratando de medida cautelar inominada, é o perigo de dano pela demora de provável sentença em favor do autor da cautelar na ação principal, cujo reconhecimento provisório se quer ver antecipado com a concessão de liminar nela requerida.

Com efeito, não demonstrada, em exame sumário, a probabilidade da existência do direito que se pretende ver reconhecido na ação principal, não há também se reconhecer, de pronto, o risco acima referido, máxime quando, no caso, em face da natureza do contrato em virtude do qual a União assumiu a dívida mobiliária do Estado-membro em face de terceiros, a suspensão liminar da execução desse contrato pela aplicação das cláusulas de garantia causa a ela, que deverá ser ré na ação futura, evidente dano.

7. Em face do exposto, indefiro o pedido de liminar, e determino a citação da Uniāo para contestar a medida cautelar inominada.

Brasília, 15 de fevereiro de 1999.

Ministro MOREIRA ALVES

Relator 